\title{
Dermatitis atópica en niños y vitamina D. Un estudio analítico retrospectivo
}

\section{Atopic dermatitis in children and vitamin D. A retrospective analytical study}

\author{
María C Viada Peláez ${ }^{1}$, Viviana Leschinsky², Andrés Gomila³. \\ 1Universidad Católica de Córdoba, Facultad de Ciencias de la Salud. Clínica Universitaria Reina Fabiola. Servicio de Pediatría. Córdoba- Argentina. \\ 2Universidad Católica de Córdoba. Clínica Universitaria Reina Fabiola. Servicio de Dermatología Pediátrica Córdoba- Argentina. \\ 3Universidad Católica de Córdoba. Clínica Universitaria Reina Fabiola. Servicio de Pediatría. Córdoba -Argentina. \\ Correspondencia: María Candela Viada Peláez, Servicio de Pediatría - Clínica Universitaria Reina Fabiola. Oncativo 1248 -X5004FHP- Córdoba, Argentina; email \\ : candeviada@hotmail.com
}

\section{Introducción}

La dermatitis atópica (DA), patología inflamatoria de la piel, es una enfermedad de distribución mundial, con una elevada prevalencia en los países desarrollados, lo que la ha convertido en una prioridad de salud. ${ }^{1}$ Su prevalencia se ha duplicado en las dos últimas décadas, sobre todo en países industrializados donde afecta hasta el $30 \%$ de la población infantil y $10 \%$ de los adultos. ${ }^{2,3}$ El tratamiento es amplio, siendo muy frecuente la falta de adherencia al mismo. Estudios recientes han demostrado que la forma activa de vitamina $\mathrm{D}$ podría ejercer efectos beneficiosos ${ }^{4}$ permitiendo la recuperación de la integridad de la barrera epidérmica.

\section{Objetivo}

Analizar la evolución clínica de la DA en pacientes pediátricos que recibieron vitamina $\mathrm{D}$ como tratamiento suplementario a través de la utilización del SCORAD.

\section{Materiales y métodos}

Diseño de tipo retrospectivo. Realizado a través de la recolección de datos obtenidos en historias clínicas de pacientes con diagnóstico de dermatitis Atópicas (basándonos en los criterios determinados por Hanifin y Rajka) que consultaron entre los meses de julio y diciembre de 2015, que utilizaron vitamina D como tratamiento. Para valorar la severidad de la DA se utilizó el SCORAD "Scoring atopic dermatitis" (Figura I) realizado al inicio del tratamiento y la planilla resultante luego de haber finalizado el tratamiento oral durante un mes con 1000 UI de vitamina D, indicado por el servicio de dermatología pediátrica.

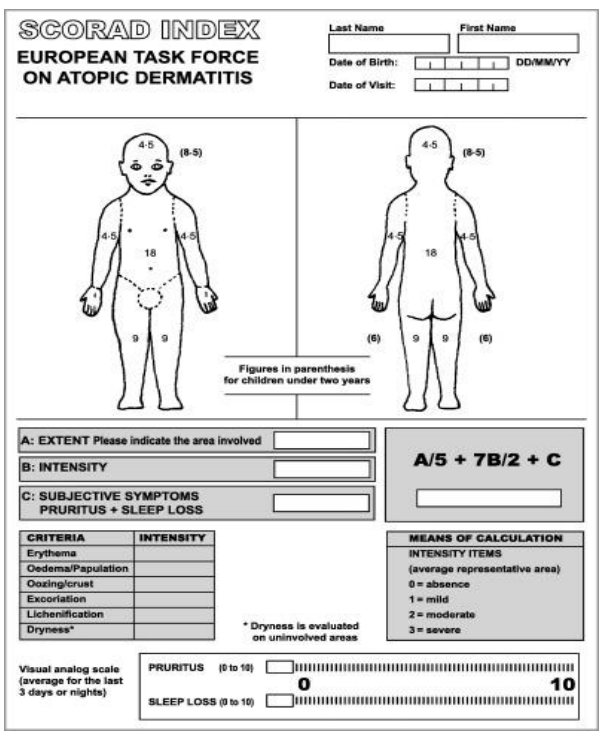

Figura I. Planilla de SCORAD

Revista Methodo: Investigación Aplicada a las Ciencias Biológicas. Universidad Católica de Córdoba. Jacinto Ríos 571 Bo Gral. Paz. X5004FXS. Córdoba. Argentina. Tel.: (54) 3514517299 / Correo: methodo@ucc.edu.ar / Web: methodo.ucc.edu.ar | ARTICULO ORIGINAL Rev. Methodo 2019;4(2):41-43 


\section{Resultados}

Se evaluaron 15 pacientes con diagnóstico de DA, 13 de ellos $(86,6 \%)$ cumplieron con los criterios de inclusión. La edad media fue de: 4 años y de sexo femenino $7(54 \%)$. El $100 \%$ de los pacientes cumplieron el tratamiento prescripto por el servicio de dermatología, con 1000 UI de vitamina D oral como tratamiento suplementario de la DA. Ningún paciente suspendió el tratamiento de base previo. Del total de la muestra 1 paciente $(8 \%)$ presentó un SCORAD inicial correspondiente a DA leve, 9 pacientes (69\%) a DA moderada y 3 pacientes $(23 \%)$ DA grave (Tabla I).

Tabla I. Cálculo de SCORAD al inicio del tratamiento

\begin{tabular}{|r|r|r|r|r|r|l|}
\hline \multicolumn{7}{|c|}{ Cálculo de SCORAD en consulta inicial } \\
\hline$N^{*}$ paciente & Fecha & Extensión & $\begin{array}{c}\text { Intensidad } \\
\text { del Brote }\end{array}$ & $\begin{array}{c}\text { Sintomas } \\
\text { Subjetivos }\end{array}$ & SCORAD & $\begin{array}{c}\text { Gravedad } \\
\text { inicial }\end{array}$ \\
\hline 1 & $14 / 7 / 2015$ & 8 & 7 & 8 & 34,1 & MODERADA \\
\hline 2 & $15 / 7 / 2015$ & 10 & 8 & 10 & 40 & MODERADA \\
\hline 3 & $20 / 7 / 2015$ & 26 & 9 & 12 & 48,7 & SEVERA \\
\hline 4 & $22 / 7 / 2015$ & 8 & 5 & 10 & 29,1 & MODERADA \\
\hline 5 & $24 / 7 / 2015$ & 15 & 7 & 8 & 35,5 & MODERADA \\
\hline 6 & $3 / 8 / 2015$ & 12 & 5 & 10 & 29,9 & MODERADA \\
\hline 7 & $22 / 7 / 2015$ & 8 & 7 & 10 & 36,1 & MODERADA \\
\hline 8 & $1 / 7 / 2015$ & 18 & 7 & 4 & 32,1 & MODERADA \\
\hline 9 & $19 / 10 / 2015$ & 24 & 8 & 8 & 40,8 & SEVERA \\
\hline 10 & $30 / 10 / 2015$ & 10 & 4 & 3 & 19 & MODERADA \\
\hline 11 & $30 / 10 / 2015$ & 12 & 3 & 2 & 14,9 & LEVE \\
\hline 12 & $14 / 8 / 2015$ & 8 & 5 & 3 & 22,1 & MODERADA \\
\hline 13 & $29 / 7 / 2015$ & 29 & 11 & 7 & 51,3 & SEVERA \\
\hline
\end{tabular}

Luego de un mes de tratamiento se calculó un nuevo índice de SCORAD; observando: un $38 \%$ de pacientes con diagnóstico de DA leve y un $62 \%$ con DA Moderada (Tabla II). Ningún paciente presentó DA grave. A su vez teniendo en cuenta la diferencia de ambos resultados, se obtuvo el porcentaje de reducción del SCORAD, observando que todos los pacientes presentaron una reducción en el índice SCORAD luego del tratamiento, con un promedio de mejoría del $45 \%$.

Tabla II. Cálculo de SCORAD al final del tratamiento

\begin{tabular}{|r|r|r|r|r|r|l|}
\hline \multicolumn{7}{|c|}{ Fálculo SCORAD al mes de tratamiento con Vitamina D } \\
\hline $\begin{array}{r}\boldsymbol{N}^{\circ} \\
\text { paciente }\end{array}$ & Fecha & Extensión & $\begin{array}{c}\text { Intensidad } \\
\text { del Brote }\end{array}$ & $\begin{array}{l}\text { Sintomas } \\
\text { Subjetivos }\end{array}$ & sCORAD & $\begin{array}{c}\text { Gravedad } \\
\text { post } \\
\text { vitamina } D\end{array}$ \\
\hline 1 & $14 / 8 / 2015$ & 0 & 3 & 8 & 18,5 & MODERADA \\
\hline 2 & $15 / 8 / 2015$ & 5 & 4 & 5 & 20 & MODERADA \\
\hline 3 & $20 / 8 / 2015$ & 14 & 5 & 8 & 28,3 & MODERADA \\
\hline 4 & $24 / 8 / 2015$ & 2 & 3 & 4 & 14,9 & LEVE \\
\hline 5 & $11 / 9 / 2015$ & 2 & 3 & 4 & 14,9 & LEVE \\
\hline 6 & $7 / 9 / 2015$ & 4 & 3 & 5 & 16,3 & MODERADA \\
\hline 7 & $20 / 8 / 2015$ & 5 & 4 & 5 & 20 & MODERADA \\
\hline 8 & $30 / 7 / 2015$ & 10 & 4 & 2 & 18 & MODERADA \\
\hline 9 & $18 / 11 / 1900$ & 10 & 4 & 3 & 19 & MODERADA \\
\hline 10 & $2 / 11 / 2015$ & 6 & 2 & 1 & 9,2 & LEVE \\
\hline 11 & $2 / 11 / 2015$ & 10 & 2 & 1 & 10 & LEVE \\
\hline 12 & $25 / 9 / 2015$ & 6 & 3 & 1 & 12,7 & LEVE \\
\hline 13 & $28 / 8 / 2015$ & 15 & 8 & 4 & 35 & MODERADA \\
\hline & & & & & & \\
\hline
\end{tabular}

\section{Conclusión}

El uso oral de vitamina D como tratamiento suplementario en niños con dermatitis atópica sugiere un impacto positivo en la evolución clínica de los pacientes estudiados. Sin embargo, se requiere de nuevos trabajos de investigación que comparen la evolución clínica de la DA entre pacientes que recibieron y pacientes que no recibieron vitamina D como parte de su tratamiento.

\section{Abstract}

\section{Introduction}

atopic dermatitis (AD), an inflammatory pathology of the skin, is a disease of worldwide distribution, with a high prevalence in developed countries, which has made it a health priority.1 Its prevalence has doubled in the last two decades; especially in industrialized countries where it affects up to $30 \%$ of the child population and $10 \%$ of adults.2,3 It can have a considerable impact on the quality of life of patients and their families. The treatment is extensive, being very frequent the lack of adherence. Recent studies have shown that the active form of vitamin $\mathrm{D}$ could have beneficial effects 4 allowing the recovery of the integrity of the epidermal barrier.

\section{Objective}

to analyze the evolution of $\mathrm{AD}$ in pediatric patients who received vitamin $\mathrm{D}$ as supplementary treatment using SCORAD.

\section{Materials and Methods}

analytical and retrospective study. Through the collection of data obtained in clinical records of patients diagnosed with AD (based on Hanifin and Rajka 's criteria) who consulted between July and December 2015, who used vitamin D as a treatment. To evaluate the severity of $\mathrm{AD}$, the SCORAD "Scoring atopic dermatitis" (Figure I) was performed at the beginning of the treatment and after finished the oral treatment for one month with $1000 \mathrm{IU}$ of vitamin D, indicated by the pediatric dermatology department.

\section{Results}

15 patients with a diagnosis of AD were initially evaluated. Of them, only $13(86.6 \%)$ met the inclusion criteria. The average age was: 4 years, and there was prevalence of females $(54 \%)$. The

Revista Methodo: Investigación Aplicada a las Ciencias Biológicas. Universidad Católica de Córdoba. Jacinto Ríos 571 Bo Gral. Paz. X5004FXS. Córdoba. Argentina. Tel.: (54) 3514517299 / Correo: methodo@ucc.edu.ar / Web: methodo.ucc.edu.ar | ARTICULO ORIGINAL Rev. Methodo 2019;4(2):41-43 
$100 \%$ of the patients complied with the treatment prescribed, with 1000 IU of oral vitamin D as a supplementary treatment for AD. No patient discontinued the previous base treatment. From the total sample 1 patient $(8 \%)$ presented an initial SCORAD corresponding to mild DA, 9 patients $(69 \%)$ to moderate and 3 patients $(23 \%)$ severe (Table I). After one month of treatment, a new SCORAD was calculated; observing: $38 \%$ of patients with mild and $62 \%$ with moderate AD (Table II). No patient presented severe type. The average improvement with this treatment was $45 \%$.

\section{Conclusion}

The oral use of vitamin D as supplementary treatment in children with AD suggests a positive impact on the clinical evolution of the patients studied. However, new research comparing the clinical course of $\mathrm{AD}$ between patients who received and patients who did not receive vitamin $\mathrm{D}$ as part of their treatment is required.

\section{Bibliografía}

1. Giachetti A, Greco MF, Scacchi MF, y cols. "Consenso Nacional de Dermatitis Atópica 2013".

http://www.sap.org.ar/uploads/consensos

2. Searing DA, Leung DY. "Vitamin D in atopic dermatitis, asthma and allergic diseases". Immunol Allergy Clin North Am Aug 2010; 30(3): 397-409.

3. Bieber T. "Atopic Dermatitis". N Engl J Med 2008; 358: 1483-1494.

4. Hata TR, Audish D, Kotol P, et col. "A randomized controlled double-blind investigation of the effects of vitamin D dietary supplementation in subjects with atopic dermatitis". J Eur Acad Dermatol Venereol. 2014 Jun; 28(6):781-9.

\section{Palabras claves}

ATOPÍA INFANTIL, SCORAD

\section{Keywords}

CHILDREN'S ATOPY, SCORAD 